\title{
ANALISIS KOMPETENSI PROFESIONAL GURU SEKOLAH DASAR NEGERI O01 SUNGAI PINANG
}

\author{
Maimunah \\ maimunahmunah1966@gmail.com \\ SD Negeri 001 Sungai Pinang, Kuantan Singingi, Indonesia
}

\begin{abstract}
The teacher plays a very important role both in planning and implementing the learning process. Therefore teachers must have professional competence that can support the ability in planning and implementing in the learning process. this research was conducted at SDN 001 Sungai Pinang. The purpose of this study was to determine how much the professional competence of teachers in Sungai Pinang 001 Elementary School. This research is a school action research. Data collection techniques used in this study were questionnaire or questionnaire techniques. From the results of the study showed that, teacher professional competence seen from the indicators mastering the competency standards and basic competencies obtained an average percentage of $71.5 \%$ good category. Indicators of developing learning materials that are taught creatively, obtained an average percentage of $75.7 \%$ good category. Indicators of developing professionalism in a sustainable manner can be seen that the average percentage reaches $80.6 \%$ good category. Indicators utilizing information and communication technology, obtained an average percentage of $81.4 \%$ in the excellent category. Based on the results of the above research, it can be concluded that the professional competence of SDN 001 Sungai Pinang Teachers, Hulu Kuantan District, Kuantan Singingi Regency is classified as good.
\end{abstract}

Keywords: professional competence, elementary school teachers

\begin{abstract}
ABSTRAK
Guru memegang peranan yang sangat penting baik dalam perencanaan maupun pelaksanaan proses pembelajaran. Oleh sebab itu guru harus memiliki kompetensi profesional yang dapat menunjang kemampuan dalam perencanaan maupun pelaksanaan dalam proses pembelajaran. penelitian ini dilakukan di SD Negeri 001 Sungai Pinang. Tujuan penelitian ini adalah untuk mengetahui seberapa besar kompetensi profesional guru di SD Negeri 001 Sungai Pinang. Penelitian ini merupakan penelitian tindakan sekolah (PTS). Teknik pengumpulan data yang digunakan dalam penelitian ini yaitu teknik angket atau kuisioner. Dari hasil penelitian menunjukan bahwa, kompetensi profesional guru dilhat dari Indikator menguasai standar kompetensi dan kompetensi dasar diperoleh rata-rata persentase sebesar 71.5\% kategori baik. Indikator mengembangkan materi pembelajaran yang diampu secara kreatif, diperoleh rata-rata persentase sebesar $75.7 \%$ kategori baik. Indikator mengembangkan keprofesionalan secara berkelanjutan dapat diketahui bahwa rata-rata persentase mencapai $80.6 \%$ kategori baik. Indikator memanfaatkan teknologi informasi dan komunikasi, diperoleh rata-rata persentase sebesar $81.4 \%$ kategori sangat baik. Berdasarkan hasil penelitian diatas, dapat disimpulkan bahwa kompetensi profesional Guru Sekolah Dasar Negeri 001 Sungai Pinang Kecamatan Hulu Kuantan, Kabupaten Kuantan Singingi tergolong baik.
\end{abstract}

Kata Kunci: kompetensi profesional, guru sekolah dasar

\begin{tabular}{|c|c|c|}
\hline Submitted & Accepted & Published \\
\hline 20 Juni 2019 & 31 Oktober 2019 & 12 November 2019 \\
\hline
\end{tabular}

\begin{tabular}{|l|c|c|c|}
\hline Citation & $:$ & $\begin{array}{c}\text { Maimunah. (2019). Analisis Kompetensi Profesional Guru Sekolah Dasar Negeri 001 Sungai Pinang. Jurnal PAJAR } \\
\text { (Pendidikan dan Pengajaran), 3(6), 1239-1246. DOI : http://dx.doi.org/10.33578/pjr.v3i6.7882. }\end{array}$
\end{tabular}

\section{PENDAHULUAN}

Guru merupakan sebuah jabatan professional maka guru diwajibkan memiliki kompetensi tertentu, yang terukur dan teruji melalui prosedur tertentu. Dalam UU No.14 Tahun 2005 dinyatakan bahwa guru sebagai pendidik profesional mempunyai tugas utama mendidik, mengajar, membimbing, mengarahkan, melatih, menilai, dan mengevaluasi siswa pada pendidikan anak usia dini pada pendidikan formal, pendidikan dasar, dan pendidikan menengah. Lebih lanjut, di dalam Undangundang Nomor 20 Tahun 2003, Pasal 39 Ayat 2 dinyatakan bahwa pendidik merupakan tenaga profesional yang bertugas merencanakan dan melaksanakan proses pembelajaran, menilai hasil pembelajaran, melakukan pembimbingan dan pelatihan, serta melakukan penelitian dan pengabdian kepada masyarakat, terutama bagi pendidik di perguruan tinggi (Rokhmaniyah dan Surandari, 2016). 
Tugas guru dalam proses pembelajaran meliputi tugas pedagogis, profesional, kepribadian, dan sosial. Sardiman (2007) mengemukakan bahwa untuk mampu melaksanaakan tugas mengajar dengan baik, guru harus memiliki kemampuan profesional, yaitu terpenuhinya sepuluh kompetensi guru, yang meliputi (1) menguasai bahan; (2) mengelola program belajar mengajar; (3) mengelola kelas; (4) penggunaan media atau sumber; (5) menguasai landasan-landasan pendidikan; (6) mengelola interaksi belajar mengajar; (7) menilai prestasi siswa untuk kepentingan pelajaran; (8) mengenal fungsi layanan bimbingan dan penyuluhan di sekolah; (9) mengenal dan menyelenggarakan administrasi sekolah, dan (10) memahami prinsip-prinsip dan menafsirkan hasil penelitian pendidikan guna keperluan pengajaran.

Pemikiran mengenai peningkatan mutu pembelajaran di atas dilatarbelakangi oleh sejumlah kenyataan. Seperti yang diungkap oleh Yayuk (2014) mengatakan: 1) masih rendahnya

\section{KAJIAN TEORETIS}

Kompetensi guru dikembangkan dengan praktik yang tercermin dalam pemilihan isi bahan yang diajarkan, pemilihan dan penerapan program pengajaran secara inovatif dan kreatif, pemikiran yang kritis, dan mengevaluasi proses pengajaran. Menurut Ciechanowska (2010), inti dari mengajar terdiri atas kompetensi komunikatif-interpretatif, dan kompetensi interpretatif dan sosial dari guru dihubungkan dengan kemampuan untuk bertindak sebagai konseling.

Mulyasa (dalam Kunandar 2010) merinci beberapa aspek atau ranah yang ada dalam konsep kompetensi, yaitu: 1) Pengetahuan (knowledge) yaitu kesadaran dalam bidang kognitif, misalnya seorang guru mengetahui cara melakukan identifikasi kebutuhan belajar, dan bagaimana melakukan pembelajaran terhadap siswa sesuai dengan kebutuhannya; 2) Pemahaman (understanding) yaitu kedalaman kognitif dan efektif yang dimiliki oleh individu. Misalnya seorang guru yang akan melaksanakan pembelajaran harus memiliki pemahaman yang baik tentang karakteristik dan kondisi peserta didik agar dapat melaksanakan pembelajaran pencapaian belajar siswa, dikarenakan guru masih menjadi titik fokus pembelajaran serta masih kentalnya tipe pembelajaran yang bercirikan teacher-directed; 2) belum mempunyai pembelajaran menumbuhkan kebiasaan berpikir produktif, yang diakibatkan dari proses pembelajaran tradisional di sekolah-sekolah. 3) sebagian besar guru memperlakukan siswa sebagai objek didik, yang cenderung mematikan potensi kreatif siswa.

Uraian di atas, dalam rangka mengetahui kompetensi profesional guru sekolah dasar Negeri 001 Sungai Pinang, khususnya pada kompetensi profesional untuk mengetahui jika kompetensi profesional guru baik maka dalam menunjang kegiatan atau aktivitas proses pembelajaran akan baik. Maka kompetensi profesional sangat penting untuk diteliti dalam mengetahui pengaruh dan kontribusinya. Adapun tujuan dari penelitian ini adalah untuk mengetahui kompetensi profesional guru di SD Negeri 001 Sungai Pinang.

secara efektif dan efisien; 3) Kemampuan (skill), yaitu sesuatu yang dimiliki oleh seseorang untuk melakukan tugas atau pekerjaan yang diberikan kepadanya. Misalnya kemampuan guru dalam memilih, dan membuat alat peraga sederhana untuk memberi kemudahan belajar kepada peserta didik; 4) Nilai, yaitu suatu standar perilaku yang telah diyakini dan secara psikologis telah menyatu dalam diri seseorang. Misalnya standar perilaku guru dalam pembelajaran (kejujuran, keterbukaan, demokratis, dan lain-lain); 5) Sikap, yaitu perasaan (senang-tidak senang, suka-tidak suka) atau reaksi terhadap suatu rangsangan yang dating dari luar. Misalnya reaksi terhadap krisis ekonomi, perasaan terhadap kenaikan gaji, dan sebagainya; 6) Minat (interest), yaitu kecenderungan seseorang untuk melakukan suatu perbuatan. Misalnya minat untuk mempelajari atau melalukan sesuatu.

Kompetensi profesional yaitu kompetensi yang berhubungan dengan tugas profesionalnya sebagai guru, meliputi: 1) Guru harus mengembangkan sikap dalam membina hubungan sosial, baik dengan kelas maupun diluar kelas; 2) 
Guru harus menyelidiki dan mendalami perbedaan peserta secara individual agar dapat melayani siswa sesuai dengan perbedaannya tersebut; 3) Guru harus dapat membangkitkan perhatian peserta didik pada materi pelajaran yang diberikan serta dapat menggunakan berbagai media dan sumber belajar yang bervariasi; 4) Guru harus dapat membangkitkan minat peserta didik untuk aktif dalam berpikir serta mencari dan menemukan sendiri pengetahuan; 5) Guru harus dapat membuat urutan dalam pemberian pelajaran dan penyesuaiannya dengan usia dan tahapan tugas perkembangan peserta didik (Uno, 2007).

Guru yang profesional diyakini mampu memotivasi siswa untuk mengoptimalkan potensinya dalam rangka pencapaian standar pendidikan yang ditetapkan. Kompetensi profesional menurut Usman (dalam Sagala, 2009) meliputi:

1. Penguasaan terhadap landasan kependidikan, dalam kompetensi ini termasuk:

a. Memahami tujuan pendidikan.

b. Mengetahui fungsi sekolah di masyarakat.

c. Mengenal prinsip-prinsip psikologi pendidikan.

2. Menguasai bahan pengajaran, artinya guru harus memahami dengan baik materi pelajaran yang diajarkan. Penguasaan terhadap materi

\section{METODE PENELITIAN}

Penelitian ini dilaksanakan di Sekolah Dasar Negeri 001 Sungai Pinang, Kecamatan Hulu, Kabupaten Kuantan Singingi sedangkan waktu pelaksanaannya pada bulan Februari 2019 s.d. Mei 2019. Subjek penelitian ini adalah seluruh guru yang ada di SD Negeri 001 Sungai Pinang yang berjumlah 10 orang guru, terdiri dari 4 guru laki-laki dan 6 guru perempuan.

Penelitian ini merupakan penelitian tindakan sekolah (PTS). Teknik pengumpulan data yang digunakan dalam penelitian ini yaitu teknik angket atau kuisioner. Menurut Sugiyono (2006), angket atau kuesioner merupakan teknik pengumpulan data yang dilakukan dengan cara memberi seperangkat pertanyaan atau pernyataan tertulis kepada responden untuk dijawab. Pengumpulan data diambil secara langsung pokok yang ada pada kurikulum maupun bahan pengayaan.

3. Kemampuan menyusun program pengajaran, mencakup kemampuan menetapkan kompetensi belajar, dan

4. Kemampuan menyusun perangkat penilaian hasil belajar dan proses pembelajaran.

Berdasarkan Permendiknas No.16 tahun 2007 dijelaskan tentang standar kualifikasi akademik dan kompetensi guru guna menunjang kompetensi profesional guru, yaitu: 1) menguasai standar kompetensi dan kompetensi dasar mata pelajaran atau bidang pengembangan yang diampu; 2) mengembangkan materi pembelajaran yang diampu secara kreatif; 3) mengembangkan keprofesionalan secara berkelanjutan dengan melakukan tindakan reflektif; 4) memanfaatkan teknologi informasi dan komunikasi untuk berkomunikasi dan mengembangkan diri.

Dengan demikian kompetensi profesional guru adalah guru yang ahli dalam merespon tugastugasnya secara tepat. Selain itu, kompetensi profesional merupakan salah satu kemampuan dasar yang harus dimiliki seorang guru. Berdasarkan uraian di atas bahwa indikator dalam Permendiknas No.16 tahun 2007 tentang standar kualifikasi akademik dan kompetensi guru dijadikan sebagai pengembangan instrumen penelitian ini.

dengan menggunakan beberapa pernyataan berdasarkan indikator yang berhubungan langsung dengan kompetensi profesional guru SD Negeri 001 Sungai Pinang.

Setelah data dikumpulkan melalui teknik kuisioner berupa angket, kemudian angket di analisis dengan beberapa tahap, yaitu:

\section{Mengolah Data}

Proses pengolahan data dengan menyeleksi, memfokuskan, dan mengabstraksikan data mentah yang telah diperoleh dari laporan penelitian. Kemudian menghitung data dengan menjumlahkan, merataratakan, dan mencari persentase. Setelah perhitungan data selesai, dilakukan penyajian data. Penyajian data adalah sekumpulan informasi yang tersusun memberi kemungkinan 
adanya penarikan kesimpulan dan pengambilan tindakan. Dengan penyajian ini dapat membantu peneliti dalam memahai apa yang sedang terjadi dan apa yang seharusnya dilakukan. Penyajian informasi ini dapat berbentuk matriks, grafik, tabel, dan bagian yang tersusun secara terpadu sehingga memudahkan peneliti dalam menentukan langkah selanjutnya yang harus dilakukan. Kegiatan penyajian data di samping sebagai kegiatan analisis juga merupakan kegiatan pengolahan data.

\section{Memverifikasi Data}

Verifikasi dapat dilakukan dengan keputusan didasarkan pada pengolahan data dan penyajian data yang merupakan jawaban atas masalah yang diangkat dalam penelitian. Dalam menentukan kriteria penilaian, maka dilakukan pengelompokkan atas 4 kriteria penilaian yaitu baik, cukup, kurang baik dan tidak baik, hal ini mengacu pada pendapat Suharsimi, (2006). Teknik analisis data dengan menggunakan rumus persentase sebagai berikut:

$P=\frac{f}{N} \times 100 \%$

Keterangan:

$\mathrm{P}=$ Angka persentase

$\mathrm{F}=$ Frekuensi yang sedang dicari persentase

$\mathrm{N}=$ Number of Cases (jumlah frekuensi/banyaknya individu)

100\% = Bilangan Tetap (Anas Sudijono, 2010)

Adapun kriteria persentase tersebut dapat dilihat pada tabel 1 berikut:

Tabel 1. Kriteria Persentase

\begin{tabular}{cc}
\hline Persentase $\%$ & Kriteria Aktivitas \\
\hline $81-100$ & Sangat Baik \\
\hline $61-80$ & Baik \\
\hline $41-60$ & Cukup Baik \\
\hline $21-40$ & Kurang Baik \\
\hline $1-20$ & Tidak Baik \\
\hline
\end{tabular}

Data penilaian keterampilan menulis narasi siswa dikumpulkan menggunakan rubrik penilaian kompetensi professional guru. Secara konvensional, penilaian kompetensi professional guru dapat dilakukan secara holistik maupun per aspek. Nurgiyontoro (2012:23) menjelaskan, bahwa penilaian terhadap tulisan siswa sebaiknya juga menggunakan rubrik penilaian yang mencakup komponen isi dan bahasa, masingmasing dengan sub komponen.
Persentase nilai dianalisis dengan menggunakan rumus yang dikemukakan oleh Abidin (2012:178) yaitu sebagai berikut:

$\mathrm{N}=\frac{\text { Skor yang Diperoleh }(S D)}{\text { Skor Ideal }(S I)} \times 100 \%$

Berdasarkan persentase yang diperoleh, dilakukan pengelompokan sesuai dengan kriteria yang dinyatakan oleh Arikunto (2006) pada tabel 2 berikut ini.

Tabel 2. Kategori Penilaian Kompetensi Profesional Guru

\begin{tabular}{cc}
\hline Persentase \% & Kriteria Aktivitas \\
\hline $81-100$ & Sangat Tinggi \\
\hline $61-80$ & Tinggi \\
\hline $41-60$ & Sedang \\
\hline $21-40$ & Rendah \\
\hline $1-20$ & Sangat Rendah \\
\hline
\end{tabular}




\section{HASIL DAN PEMBAHASAN}

Setelah data kompetensi profesional guru didapat dan kemudian dihitung, selanjutnya penyajian dan analisis data kompetensi profesional guru di Sekolah Dasar Neger 001 Sungai Pinang disajikan berdasarkan per indikator penilaian. Empat indikator tersebut berupa 1) menguasai standar kompetensi dan kompetensi dasar mata pelajaran atau bidang pengembangan yang diampu; 2) mengembangkan materi pembelajaran yang diampu secara kreatif; 3) mengembangkan keprofesionalan secara berkelanjutan; 4) memanfaatkan teknologi informasi dan komunikasi. Untuk lebih jelasnya dideskripsikan sebagai berikut:

\section{Indikator Menguasai Standar Kompetensi dan Kompetensi Dasar \\ Berdasarkan teknik analisis data} kompetensi profesional guru Sekolah Dasar Negeri 001 Sungai Pinang ditinjau dari indikator menguasai standar kompetensi dan kompetensi dasar mata pelajaran atau bidang pengembangan yang diampu, dapat diketahui dari tanggapan responden penelitian. Untuk lebih jelasnya dapat dilihat dari tabel 3 berikut ini:

Tabel 3. Rekapitulasi Hasil Penilaian Menguasai Standar Kompetensi dan Kompetensi Dasar

\begin{tabular}{clcc}
\hline No & \multicolumn{1}{c}{ Indikator Penilaian } & Nilai (\%) & Kategori \\
\hline $\mathbf{1}$ & $\begin{array}{l}\text { Merencanakan kegiatan proses pembelajaran } \\
\text { sesuai dengan standar kompetensi dan } \\
\text { kompetensi dasar }\end{array}$ & 90 & Sangat Baik \\
\hline $\mathbf{2}$ & $\begin{array}{l}\text { Membuat perangkat pembelajaran yang } \\
\text { sesuai dengan standar kompetensi dan } \\
\text { kompetensi dasar yang akan dicapai }\end{array}$ & 60 & Cukup \\
\hline $\mathbf{3}$ & $\begin{array}{l}\text { Mengembangkan standar kompetensi dan } \\
\text { kompetensi dasar ke dalam indikator yang } \\
\text { terukur }\end{array}$ & 80 & Baik \\
\hline $\mathbf{4}$ & $\begin{array}{l}\text { Mengembangkan tujuan pembelajaran sesuai } \\
\text { kompetensi dasar yang akan dicapai }\end{array}$ & 70 & Cukup Baik \\
\hline $\mathbf{5}$ & $\begin{array}{l}\text { Membuat kaitan antara standar kompetensi } \\
\text { dan kompetensi dasar yang akan dipelajari }\end{array}$ & 50 & Sangat Baik \\
\hline $\mathbf{6}$ & $\begin{array}{l}\text { Menyampaikan tujuan pembelajaran yang } \\
\text { dilaksanakan dengan menggunakan kata-kata } \\
\text { operasional }\end{array}$ & 85 & Baik \\
\hline $\mathbf{7}$ & $\begin{array}{l}\text { Mengembangkan materi pelajaran yang akan } \\
\text { diajarkan }\end{array}$ & 77 & Cukup Baik \\
\hline $\begin{array}{l}\text { Tidak memilih kata-kata operasional yang } \\
\text { sesuai dengan tujuan pembelajaran pada lima } \\
\text { mata pelajaran sekolah dasar }\end{array}$ & 60 & Baik \\
\hline \multicolumn{1}{c}{ Rata-rata } & 71.5 & \\
\hline
\end{tabular}

Berdasarkan data pada tabel 3 di atas, diketahui rekapitulasi analisis kompetensi profesional guru Sekolah Dasar Negeri 011 Sungai Pinang ditinjau dari indikator menguasai standar kompetensi dan kompetensi dasar mata pelajaran atau bidang pengembangan yang diampu, diperoleh rata-rata persentase sebesar 71.5\%. Berdasarkan kriteria penilaian yang ditetapkan maka dapat disimpulkan bahwa analisis kompetensi profesional guru ditinjau dari indikator menguasai standar kompetensi dan kompetensi dasar mata pelajaran atau bidang pengembangan yang diampu tergolong baik.

$\begin{array}{llr}\text { Indikator Mengembangkan } & \text { Materi } \\ \text { Pembelajaran yang Diampu Secara Kreatif } \\ \text { Berdasarkan } & \text { hasil analisis data } & \text { ditinjau } \\ \text { dari } & \text { indikator } & \text { mengembangkan materi }\end{array}$


pembelajaran yang diampu secara kreatif, dapat diketahui dari tanggapan responden penelitian.
Untuk lebih jelasnya dapat dilihat dari tabel 3 berikut ini:

Tabel 4. Rekapitulasi Hasil Penilaian Indikator Mengembangkan Materi Pembelajaran yang Diampu Secara Kreatif

\begin{tabular}{clcc}
\hline No & \multicolumn{1}{c}{ Indikator Penilaian } & Nilai (\%) & Kategori \\
\hline $\mathbf{1}$ & $\begin{array}{l}\text { Menjabarkan materi pelajaran sekolah dasar dari } \\
\text { sumber yang berbeda sesuai dengan tingkat } \\
\text { perkembangan peserta didik }\end{array}$ & 70 & Baik \\
\hline $\mathbf{2}$ & $\begin{array}{l}\text { Menggunakan media pembelajaran yang menarik } \\
\text { dalam menjelaskan materi pelajaran }\end{array}$ & 85 & Sangat Baik \\
\hline $\mathbf{3}$ & $\begin{array}{l}\text { Mencari informasi terkait materi pelajaran dari } \\
\text { berbagai sumber yang relevan }\end{array}$ & 75 & Sangat Baik \\
\hline $\mathbf{4}$ & $\begin{array}{l}\text { Menggunakan metode dan strategi pembelajaran } \\
\text { yang bervariasi dalam pembelajarana }\end{array}$ & 85 & Baik \\
\hline $\mathbf{5}$ & $\begin{array}{l}\text { Memilih dan menyesuaikan metode atau strategi } \\
\text { pembelajaran dengan materi yang akan diajarkan }\end{array}$ & 70 & Sangat Baik \\
\hline $\mathbf{6}$ & $\begin{array}{l}\text { Mengembangkan materi pelajaran dari sumber yang } \\
\text { berbeda }\end{array}$ & 60 & 85 \\
\hline $\mathbf{7}$ & $\begin{array}{l}\text { Melibatkan siswa secara aktif dalam kegiatan } \\
\text { pembelajaran kelompok dengan menggunakan media } \\
\text { dan alat bantu yang menarik dan bervariasi }\end{array}$ & 75.7 \\
\hline
\end{tabular}

Berdasarkan data pada tabel 4 di atas, diketahui rekapitulasi analisis kompetensi profesional guru Sekolah Dasar Negeri 001 Sungai Pinang ditinjau dari indikator mengembangkan materi pembelajaran yang diampu secara kreatif, diperoleh rata-rata persentase sebesar $75.7 \%$. Berdasarkan kriteria penilaian yang ditetapkan maka dapat disimpulkan bahwa analisis kompetensi profesional guru ditinjau dari indikator mengembangkan materi pembelajaran yang diampu secara kreatif tergolong baik.

\section{Indikator Mengembangkan Keprofesionalan Secara Berkelanjutan}

Berdasarkan analisis data tentang indikator mengembangkan keprofesionalan secara berkelanjutan dengan melakukan tindakan reflektif, dapat diketahui dari tanggapan responden penelitian. Untuk lebih jelasnya dapat dilihat dari tabel 5 berikut ini:

Tabel 5. Rekapitulasi Hasil Penilaian Indikator Mengembangkan Keprofesionalan Secara Berkelanjutan

\begin{tabular}{clcc}
\hline No & \multicolumn{1}{c}{ Indikator Penilaian } & Nilai $\mathbf{\%})$ & Kategori \\
\hline $\mathbf{1}$ & $\begin{array}{l}\text { Mengembangkan alat evaluasi pembelajaran dengan } \\
\text { standar keprofesionalan }\end{array}$ & 85 & Sangat Baik \\
\hline $\mathbf{2}$ & $\begin{array}{l}\text { Melakukan perbandingan aktivitas yang sudah } \\
\text { dilakukan dan kinerja yang dicapai dengan standar } \\
\text { keprofesionalan }\end{array}$ & 80 & Baik \\
\hline $\mathbf{3}$ & Merefleksi kinerja sendiri secara terus menerus & 70 & Baik \\
\hline $\mathbf{4}$ & $\begin{array}{l}\text { Meminta guru lain untuk memberikan saran terhadap } \\
\text { kinerja saya secara continue }\end{array}$ & 90 & Sangat Baik \\
\hline $\mathbf{5}$ & $\begin{array}{l}\text { Meminta bantuan kepada kepala sekolah sebagai } \\
\text { penilai dalam menentukan tingkat ke profesionalan } \\
\text { dalam mengajar }\end{array}$ & 90 & Sangat Baik \\
\hline
\end{tabular}




\begin{tabular}{clcc}
\hline $\mathbf{6}$ & $\begin{array}{l}\text { Mengembangkan alat evaluasi pembelajaran dengan } \\
\text { standar keprofesionalan }\end{array}$ & 85 & Sangat Baik \\
\hline $\mathbf{7}$ & $\begin{array}{l}\text { Berusaha mengembangkan keprofesionalan dalam } \\
\text { penggunaan metoda mengajar secara berkelanjutan }\end{array}$ & 75 & Baik \\
\hline $\mathbf{8}$ & $\begin{array}{l}\text { Berusaha meningkatkan keprofesionalan secara } \\
\text { berkelanjutan berdasarkan hasil refleksi dan informasi }\end{array}$ & 70 & Bai \\
\hline \multicolumn{2}{c}{ Rata-rata } & 80.6 & Baik \\
\hline
\end{tabular}

Berdasarkan data pada tabel 5 di atas, diketahui rekapitulasi analisis kompetensi profesional guru Sekolah Dasar Negeri 001 Sungai Pinang ditinjau dari indikator mengembangkan keprofesionalan secara berkelanjutan dengan melakukan tindakan reflektif, dapat diketahui bahwa rata-rata persentase mencapai $80.6 \%$. Berdasarkan kriteria penilaian yang ditetapkan maka dapat disimpulkan bahwa analisis kompetensi profesional guru dilihat dari indikator mengembangkan keprofesionalan secara berkelanjutan dengan melakukan tindakan reflektif tergolong baik.

\section{Indikator Memanfaatkan Teknologi Informasi dan Komunikasi}

Berdasarkan hasil analisis kompetensi dari indikator memanfaatkan teknologi informasi dan komunikasi untuk berkomunikasi dan mengembangkan diri, dapat diketahui dari tanggapan responden penelitian. Untuk lebih jelasnya dapat dilihat dari tabel 6 di bawah ini:

Tabel 6. Rekapitulasi Hasil Penilaian Indikator Mengembangkan Keprofesionalan Secara Berkelanjutan

\begin{tabular}{|c|c|c|c|}
\hline No & Indikator Penilaian & Nilai (\%) & Kategori \\
\hline 1 & $\begin{array}{lccc}\begin{array}{l}\text { Memanfaatkan } \\
\text { berkomunikasi }\end{array} & \text { teknologi } & \text { informasi } & \text { dalam } \\
\text { pembelajaran } & & \text { pengembangan } & \text { materi } \\
\end{array}$ & 90 & Sangat Baik \\
\hline 2 & $\begin{array}{l}\text { Memanfaatkan teknologi informasi } \\
\text { pengembangan diri }\end{array}$ & 85 & Sangat Baik \\
\hline 3 & $\begin{array}{l}\text { Memanfaatkan teknologi } \begin{array}{c}\text { komunikasi } \\
\text { pengembangan kemampuan keprofesionalan }\end{array} \\
\end{array}$ & 80 & Baik \\
\hline 4 & $\begin{array}{l}\text { Menggunakan teknologi informasi dan komunikasi } \\
\text { dalam menyampaikan materi pelajaran }\end{array}$ & 75 & Baik \\
\hline 5 & $\begin{array}{l}\text { Mencari informasi tentang teknologi yang menunjang } \\
\text { materi pelajaran yang akan disampaikan }\end{array}$ & 75 & Baik \\
\hline 6 & $\begin{array}{l}\text { Menggunakan teknologi informasi dan komunikasi } \\
\text { dalam pengembangan alat evaluasi }\end{array}$ & 80 & Baik \\
\hline \multirow[t]{2}{*}{7} & $\begin{array}{lcccr}\text { Berusaha } & \text { mencari } & \text { dan } & \text { menggunakan } & \text { teknologi } \\
\text { informasi } & \text { dan } & \text { komunikasi } & \text { dalam } & \text { upaya } \\
\text { pengembangan diri } & \text { melalui proses } & \text { kegiatan belajar } \\
\text { mengajar } & & & & \\
\end{array}$ & 85 & Sangat Baik \\
\hline & Rata-rata & 81.4 & Sangat Baik \\
\hline
\end{tabular}

Berdasarkan data pada tabel 6 di atas, diketahui rekapitulasi analisis kompetensi profesional guru Sekolah Dasar Negeri 001 Sungai Pinang ditinjau dari indikator memanfaatkan teknologi informasi dan komunikasi, diperoleh rata-rata persentase sebesar $81.4 \%$. Berdasarkan kriteria penilaian yang ditetapkan maka dapat disimpulkan bahwa analisis kompetensi profesional guru ditinjau dari indikator memanfaatkan teknologi informasi dan 


\section{SIMPULAN DAN REKOMENDASI}

Berdasarkan hasil penelitian dan analisis yang telah dilakukan dapat disimpulkan bahwa kompetensi profesional guru Sekolah Dasar Negeri 001 Sungai Pinang Kecamatan Hulu Kuantan, Kabupaten Kuantan Singingi tergolong baik. Hal ini ditunjukkan oleh hasil analisis indikator sebagai berikut:

1. Indikator menguasai standar kompetensi dan kompetensi dasar diperoleh rata-rata persentase sebesar $71.5 \%$ kategori baik.

2. Indikator mengembangkan materi pembelajaran yang diampu secara kreatif, diperoleh rata-rata persentase sebesar $75.7 \%$ kategori baik.

3. Indikator mengembangkan keprofesionalan secara berkelanjutan dapat diketahui bahwa rata-rata persentase mencapai $80.6 \%$ kategori baik.

\section{DAFTAR PUSTAKA}

Arikunto, S. (2006). Prosedur Penelitian Suatu pendekatan Praktek. Jakarta: Rineka Cipta.

Sardiman, A.M. (2007) .Interaksi dan Motivasi Belajar Mengajar. Jakarta: PT. Raja Grafindo Persada.

B. Uno, H. (2007). Profesi Kependidikan. Jakarta : Bumi Aksara

Ciechanowska, D. (2010). Teacher Competence and its Importance in Academic Educationfor Prospective Teachers. General and Profesional Educaion, 1, 1220.

Depdiknas. (2005). Undang-Undang Nomor 14 Tahun 2005, Tentang Guru dan Dosen. Jakarta: Depdiknas.

Depdiknas. (2003). Undang-undang RI No.20 tahun 2003. Jakarta: Sistem Pendidikan Nasional.

Kunandar. (2010). Guru Profesional Implementasi Kurikulum Tingkat Satuan Pendidikan (KTSP) dan Persiapan Menghadapi Sertifikasi Guru. Jakarta: Rajwali Press.
4. Indikator memanfaatkan teknologi informasi dan komunikasi, diperoleh rata-rata persentase sebesar $81.4 \%$ kategori sangat baik.

Berdasarkan hasil penelitian dan kesimpulan yang telah dipaparkan, maka dapat peneliti sarankan bahwa: 1) Untuk selalu mendukung dan memberikan motivasi pada guruguru agar memiliki kemampuan profesionalisme dalam melakasanakan tugasnya; 2) Selalu memantau dan membimbing guru dalam meningkatan kompetensi keprofesionalannya; dan 3) untuk peneliti selanjutnya yang ingin melakukan penelitian yang sejenis agar di dalam penelitiannya menambahkan atau menggunakan lembar observasi dan wawancara agar lebih mendalam analisisnya tentang kompetensi profesional guru.

Peraturan Menteri Pendidikan Nasional Republik indonesia Nomor 16 tahun 2007 tentang Standar Kualifikasi Akademik dan Kompetensi Guru. Jakarta: Sistem Pendidikan Nasional.

Rokhmaniyah \& Surandari, K.C. (2016). Lesson Study Pengembangan Bahan Pembelajaran Berbasis Potensi Lokal untuk Meningkatkan Kompetensi Profesional Guru SD di Kabupaten Kebumen. Jurnal Premiere Educandum, 6(2), 162-173.

Sagala, S. (2009). Kemampuan Profesional Guru dan Tenaga Kependidikan. Bandung: Alfabeta.

Sudijono, A. (2010). Pengantar Statistik Pendidikan. Jakarta: Raja Grafindo Persada.

Yayuk, E. (2014). Pemetaan Kompetensi Guru Bersertifikat Pendidik untuk Pemanfaatan Media TIK dalam Kegiatan Pembelajaran di Sekolah Dasar. Jurnal Premiere Educandum, 4(2), 205-215. 